\title{
PHYSICO-CHEMICAL PROCESSES FROM THE X70 STEEL MAKING AND CONTINUOUS CASTING THAT INFLUENCE ITS PROPERTIES
}

\author{
Gigi STRAT ${ }^{a^{*}}$, Maria VLADa, Gelu MOVILEANUb, Florentina POTECAȘUa \\ a"Dunarea de Jos" University of Galati, Faculty of Engineering, Romania

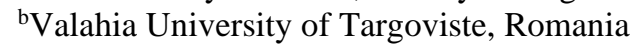 \\ e-mail: gigistrat1967@gmail.com
}

\begin{abstract}
The paper presents the processes of elaboration and casting that favourably influence the properties of microalloyed steel.

High strength microalloyed steel used to manufacture main oil and gas pipelines must meet, in addition to special technical conditions, economic conditions, which contribute to the protection of the environment. Secondary treatment in LF and RH installations as well as automatically controlled continuous casting can also help improving the physical, mechanical and corrosion properties of the products obtained from these steels. The making of X70 steels at OLD1(Liberty Steel Group), according to existing technology, is the peak of performance at the current stage.

Blowing oxygen and argon into the converter is done according to a Blowing Pattern that takes into account the gas flow and the distance from the head of the blowing lance to the surface of the metal bath. Deoxidation and microalloying of the X70 steel take place in the casting ladle and during the secondary treatment in LF and $R H$.

For deoxidation and microalloying, some ferro-alloys which have strictly limited content of harmful elements $(P, S)$ are used. LF microalloying materials such as: Mn-99\%, Al-99\%, FeTi-70\%, FeV-80\%, FeNb-65\%, Ca-99\% or SiCa60/30\% are introduced into the steel as tubular ferro-alloys and not chunks. In this way, a superior assimilation and homogeneous diffusion of the elements into the metal bath are achieved.

Secondary treatment of the X70 steel for chemical and thermal homogenization of the metal bath is achieved by advanced metal bath desulfurization using synthetic slag, lime and bauxite. Vacuum degassing with RH procedure is done to reduce hydrogen from $8-9$ ppm to less than $2 \mathrm{ppm}$. At the continuous casting of these steel types, the bubbling is not used because it is intended that the floating of inclusions be easier on the surface of the metal bath.
\end{abstract}

KEYWORDS: properties, deoxidation, microalloying, steel, LD converter

\section{Introduction}

The launching point in the research and development of high-strength micro-alloy steels was represented by the brands used in the construction of major oil and natural gas pipelines, the steels developed and processed for use in extreme conditions, from the Arctic to the desert areas, from depths greater than $2000 \mathrm{~m}$, to the altitudes necessary to cross mountain ranges, buses that extend thousands of kilometres and which must satisfy, in addition to the special technical conditions that ensure their safety in use, economic conditions and protection of the environment.

By performing the tasks elaborated on the basis of the mathematical models and by optimizing the parameters of the main processes in the elaboration and casting of the high strength mechanical steels, their properties can be improved. The steel industry has responded to current requirements by developing new steel brands that can be used in different 
industrial sectors and which have a common set of characteristics

These steels are called HSLA - high strength microalloyed steels [1]. All these features are found in high strength microalloyed steels, which are produced and developed under different brands by the major steel producers around the world [2]. This category also includes X70 steel according to API5L-91.

X70 steel, by its characteristics, is suitable for the manufacture of main pipes in the current state of their technologies. Medium alloy steel would have required a higher consumption of alloying elements and thus higher production prices.

\section{The experimental part}

The main reference properties for X70 steels:

- high mechanical strength;

- high weldability;

- high resistance even at low temperatures;

- good plasticity characteristics;

- good resistance to atmospheric and marine corrosion;

- high economic efficiency in terms of production costs.

Tables 1-4 present the main mechanical properties and chemical compositions of X70 steel type.

Table 1. Variation of mechanical strength of X70 microalloyed steels according to API-5L/95

\begin{tabular}{|c|c|c|}
\hline Yield Strength [MPa] & Tensile strength [MPa] & Rp..2/Ts \\
\hline $485-615$ & $570-700$ & 0.93 \\
\hline
\end{tabular}

Table 2. X70 microalloyed steels, according to API-5L/95

\begin{tabular}{|c|c|c|c|c|c|c|c|}
\hline $\begin{array}{c}\text { Chemical } \\
\text { analysis }\end{array}$ & $\begin{array}{l}\text { Acceptance } \\
\text { limits }\end{array}$ & $\begin{array}{c}\text { Over tolerant } \\
\text { limits }\end{array}$ & Target & $\begin{array}{c}\text { Chemical } \\
\text { analysis }\end{array}$ & $\begin{array}{l}\text { Acceptance } \\
\text { limits }\end{array}$ & $\begin{array}{c}\text { Over tolerant } \\
\text { limits }\end{array}$ & Target \\
\hline Element & $\begin{array}{l}\operatorname{Max} \\
(\%)\end{array}$ & $\begin{array}{l}\operatorname{Max} \\
(\%)\end{array}$ & $\begin{array}{c}\text { Target } \\
(\%)\end{array}$ & Element & $\begin{array}{l}\text { Max } \\
(\%)\end{array}$ & $\begin{array}{l}\operatorname{Max} \\
(\%)\end{array}$ & $\begin{array}{c}\text { Target } \\
(\%)\end{array}$ \\
\hline C & & 0.09 & 0.07 & Mo & & 0.13 & 0.12 \\
\hline Mn & & 1.65 & 1.55 & $\mathrm{Ni}$ & & 0.20 & \\
\hline $\mathbf{P}$ & 0.02 & 0.018 & 0.02 & $\mathrm{Cu}$ & & 0.10 & \\
\hline $\mathbf{S}$ & 0.01 & 0.05 & 0.03 & B & & 0.0005 & 0.0003 \\
\hline $\mathbf{S i}$ & & 0.40 & 0.30 & $\mathrm{Ca}$ & & 0.0015 & 0.001 \\
\hline Al & & 0.05 & 0.04 & $\mathrm{~N}$ & & 0.007 & 0.006 \\
\hline Nb & 0.07 & 0.06 & 0.05 & $\mathrm{~V}+\mathrm{Nb}+\mathrm{Ti}$ & 0.15 & 0.15 & \\
\hline $\mathbf{V}$ & 0.10 & 0.008 & & $\mathrm{~V}+\mathrm{Nb}$ & 0.14 & 0.14 & \\
\hline $\mathrm{Ti}$ & & 0.025 & 0.02 & $\mathrm{Ce}$ & 0.39 & 0.39 & \\
\hline $\mathrm{Cr}$ & & 0.20 & & & & & \\
\hline
\end{tabular}

Table 3. X70-M21 microalloyed steels, according to the Arcelor Mittal Galati-Metallurgical Handbook

\begin{tabular}{|c|c|c|c|c|c|c|c|c|c|c|c|c|c|c|c|c|}
\hline & $\mathbf{C}$ & $\mathbf{M n}$ & $\mathbf{S i}$ & $\mathbf{P}$ & $\mathbf{S}$ & $\mathbf{A l}$ & $\mathbf{N}_{\mathbf{2}}$ & $\mathbf{H}_{\mathbf{2}}$ & $\mathbf{C u}$ & $\mathbf{C r}$ & $\mathbf{N i}$ & $\mathbf{M o}$ & $\mathbf{N b}$ & $\mathbf{T i}$ & $\mathbf{V}$ & $\mathbf{C a}$ \\
\hline $\begin{array}{l}\text { Min } \\
(\boldsymbol{\%})\end{array}$ & 0.06 & 1.45 & 0.25 & & & 0.02 & & & & & & 0.12 & 0.045 & 0.015 & & 0.0005 \\
\hline $\begin{array}{l}\text { Max } \\
(\boldsymbol{\%})\end{array}$ & 0.075 & 1.6 & 0.4 & 0.01 & 0.002 & 0.05 & 0.007 & $2 \mathrm{ppm}$ & 0.1 & 0.2 & 0.2 & 0.13 & 0.055 & 0.025 & 0.008 & 0.0015 \\
\hline
\end{tabular}


THE ANNALS OF “DUNAREA DE JOS” UNIVERSITY OF GALATI

FASCICLE IX. METALLURGY AND MATERIALS SCIENCE

No. 1 - 2019, ISSN 2668-4748; e-ISSN 2668-4756

Article DOI: $\underline{\text { https://doi.org/10.35219/mms.2019.1.09 }}$

Table 4. X70-T15 microalloyed steels, according to the Arcelor Mittal Galati-Metallurgical Handbook

\begin{tabular}{|c|c|c|c|c|c|c|c|c|c|c|c|c|c|c|}
\hline \multicolumn{2}{|c|}{ Chemical analysis } & $\mathbf{C}$ & Mn & Si & Al & $\mathbf{P}$ & $\mathbf{S}$ & $\mathbf{N}_{2}$ & Mo & $\mathrm{Cr}$ & $\mathbf{N b}$ & $\mathbf{T i}$ & $\mathbf{C a}$ & $\mathbf{H}_{2}$ \\
\hline \multirow{3}{*}{ T15 } & $\min (\%)$ & 0.060 & 1.600 & 0.200 & 0.020 & & & & 0.110 & 0.25 & 0.055 & 0.015 & 0.0005 & \multirow{3}{*}{$\max .2$} \\
\hline & $\max (\%)$ & 0.075 & 1.750 & 0.350 & 0.060 & 0.015 & 0.005 & 0.007 & 0.120 & 0.35 & 0.065 & 0.025 & 0.0015 & \\
\hline & Target $(\%)$ & 0.068 & 1.680 & 0.280 & 0.040 & 0.012 & 0.003 & 0.006 & 0.115 & 0.30 & 0.060 & 0.020 & 0.0010 & \\
\hline
\end{tabular}

\subsection{Steelmaking and continuous casting of X70}

The following materials, installations and some specific operations are used in the X70 steelmaking process [3-5]:

- Technologically selected scrap iron;

- Desulphurized cast iron at\% S = 20 ppm and advanced slag removed;

- Converter with functional bubbling and slag retention, calibrated;

- Clean casting pot with functional bubbling;

- Recycled steel is not inserted in the metal load;

- Bubbling only with argon for the entire duration of the breath;

- Intermediate stop for advanced slag evacuation and resumption of blowing with additional quantity of 1-ton lime [8];

- Minimum 3 minutes post bubble (oxygen activity $\leq 700 \mathrm{ppm}$ and phosphorus $\leq 0.006 \%$ );
- The calculation of the necessary alloys is made on the lower limit of each element;

- Electrolytic manganese will be used during the evacuation and the ferroalloys will be administered with 1-minute breaks between them;

- Steel bubbling after evacuation will be done through a porous plug without the discovery of the metal bath;

- LF treatment (advanced steel bubbling, heating and desulphurization);

- Advanced desulfurization with lime, bauxite and synthetic slag;

- Correction of chemical analysis and microalloys with tub ferroalloys of $\mathrm{Nb}, \mathrm{V}, \mathrm{Ti}$ and $\mathrm{SiCa}$;

- HR treatment for 15 minutes minimum vacuum degassing;

- The batches do not bubble for about 15-20 minutes before casting begins to float inclusions in the slag [5].

Table 5. Chemical compositions corresponding to X70 steel making batch (\%), according to the OLD1-Arcelor Mittal Galati spectral laboratory analysis

\begin{tabular}{|c|c|c|c|c|c|c|c|c|c|}
\hline $\begin{array}{r}\text { Cod } \\
\text { Element }\end{array}$ & $\begin{array}{c}\text { Desulphurized } \\
\text { cast iron }\end{array}$ & $\begin{array}{c}\text { End of } \\
\text { blowing }\end{array}$ & $\begin{array}{l}\text { Steel after } \\
\text { evacuation }\end{array}$ & $\begin{array}{l}\text { Steel in LF, } \\
\text { first sample }\end{array}$ & $\begin{array}{c}\text { Steel in LF, } \\
\text { second } \\
\text { sample }\end{array}$ & $\begin{array}{c}\text { Steel in LF, } \\
\text { the third } \\
\text { sample }\end{array}$ & $\begin{array}{c}\text { Steel in LF, } \\
\text { fourth } \\
\text { sample }\end{array}$ & $\begin{array}{l}\text { Steel in LF, } \\
\text { last sample }\end{array}$ & $\begin{array}{c}\text { Final sample } \\
\text { from } \\
\text { distributor }\end{array}$ \\
\hline $\mathrm{C}$ & 4.7196 & 0.0555 & 0.0524 & 0.0602 & 0.0677 & 0.0761 & 0.0723 & 0.0742 & 0.0728 \\
\hline Mn & 0.5105 & 0.0824 & 1.2704 & 1.3102 & 1.3115 & 1.5012 & 1.4937 & 1.4843 & 1.4696 \\
\hline $\mathbf{S i}$ & 0.6787 & 0.0010 & 0.2086 & 0.1661 & 0.2510 & 0.2813 & 0.2631 & 0.2646 & 0.2729 \\
\hline $\mathbf{P}$ & 0.0767 & 0.0048 & 0.0052 & 0.0059 & 0.0064 & 0.0069 & 0.0066 & 0.0068 & 0.0070 \\
\hline $\mathbf{S}$ & 0.0036 & 0.0090 & 0.0069 & 0.0044 & 0.0030 & 0.0014 & 0.0013 & 0.0013 & 0.0012 \\
\hline Al & 0.0031 & 0.1753 & 0.0151 & 0.0232 & 0.0308 & 0.0316 & 0.0342 & 0.0393 & 0.0444 \\
\hline $\mathbf{N i}$ & 0.0016 & 0.0081 & 0.0086 & 0.0085 & 0.0084 & 0.0086 & 0.0085 & 0.0085 & 0.0085 \\
\hline $\mathbf{C u}$ & 0.0063 & 0.0112 & 0.0136 & 0.0136 & 0.0138 & 0.0146 & 0.0146 & 0.0144 & 0.0145 \\
\hline $\mathrm{Cr}$ & 0.0186 & 0.0063 & 0.0088 & 0.0093 & 0.0097 & 0.0110 & 0.0108 & 0.0112 & 0.0157 \\
\hline $\mathbf{T i}$ & 0.0318 & 0.0001 & 0.0006 & 0.0007 & 0.0015 & 0.0209 & 0.0224 & 0.0206 & 0.0166 \\
\hline Mo & 0.0010 & 0.0009 & 0.1172 & 0.1184 & 0.1182 & 0.1246 & 0.1251 & 0.1251 & 0.1245 \\
\hline $\mathbf{N b}$ & 0.0010 & 0.0003 & 0.0014 & 0.0013 & 0.0016 & 0.0420 & 0.0422 & 0.0451 & 0.0466 \\
\hline $\mathbf{V}$ & 0.0072 & 0.0004 & 0.0014 & 0.0015 & 0.0017 & 0.0020 & 0.0019 & 0.0017 & 0.0018 \\
\hline $\mathbf{C a}$ & 0.0000 & 0.0166 & 0.0001 & 0.0001 & 0.0033 & 0.0103 & 0.0047 & 0.0039 & 0.0006 \\
\hline Sn & 0.0042 & 0.0008 & 0.0010 & 0.0011 & 0.0013 & 0.0014 & 0.0014 & 0.0012 & 0.0015 \\
\hline B & 0.0006 & 0.0000 & 0.0001 & 0.0001 & 0.0002 & 0.0002 & 0.0002 & 0.0002 & 0.0003 \\
\hline $\mathbf{N}$ & 0.0000 & 0.0057 & 0.0024 & 0.0010 & 0.0011 & 0.0069 & 0.0033 & 0.0006 & 0.0047 \\
\hline $\mathbf{P b}$ & 0.0010 & 0.0005 & 0.0020 & 0.0022 & 0.0022 & 0.0024 & 0.0028 & 0.0027 & 0.0026 \\
\hline $\mathbf{Z r}$ & 0.0010 & 0.0003 & 0.0019 & 0.0020 & 0.0020 & 0.0025 & 0.0024 & 0.0024 & 0.0024 \\
\hline Zn & 0.0017 & 0.0042 & 0.0060 & 0.0065 & 0.0043 & 0.0028 & 0.0089 & 0.0059 & 0.0020 \\
\hline Co & 0.0010 & 0.0021 & 0.0024 & 0.0024 & 0.0023 & 0.0026 & 0.0025 & 0.0025 & 0.0025 \\
\hline $\mathbf{F e}$ & 93.9087 & 99.6261 & 98.2768 & 98.2643 & 98.1609 & 97.8518 & 97.8813 & 97.8875 & 97.8962 \\
\hline
\end{tabular}




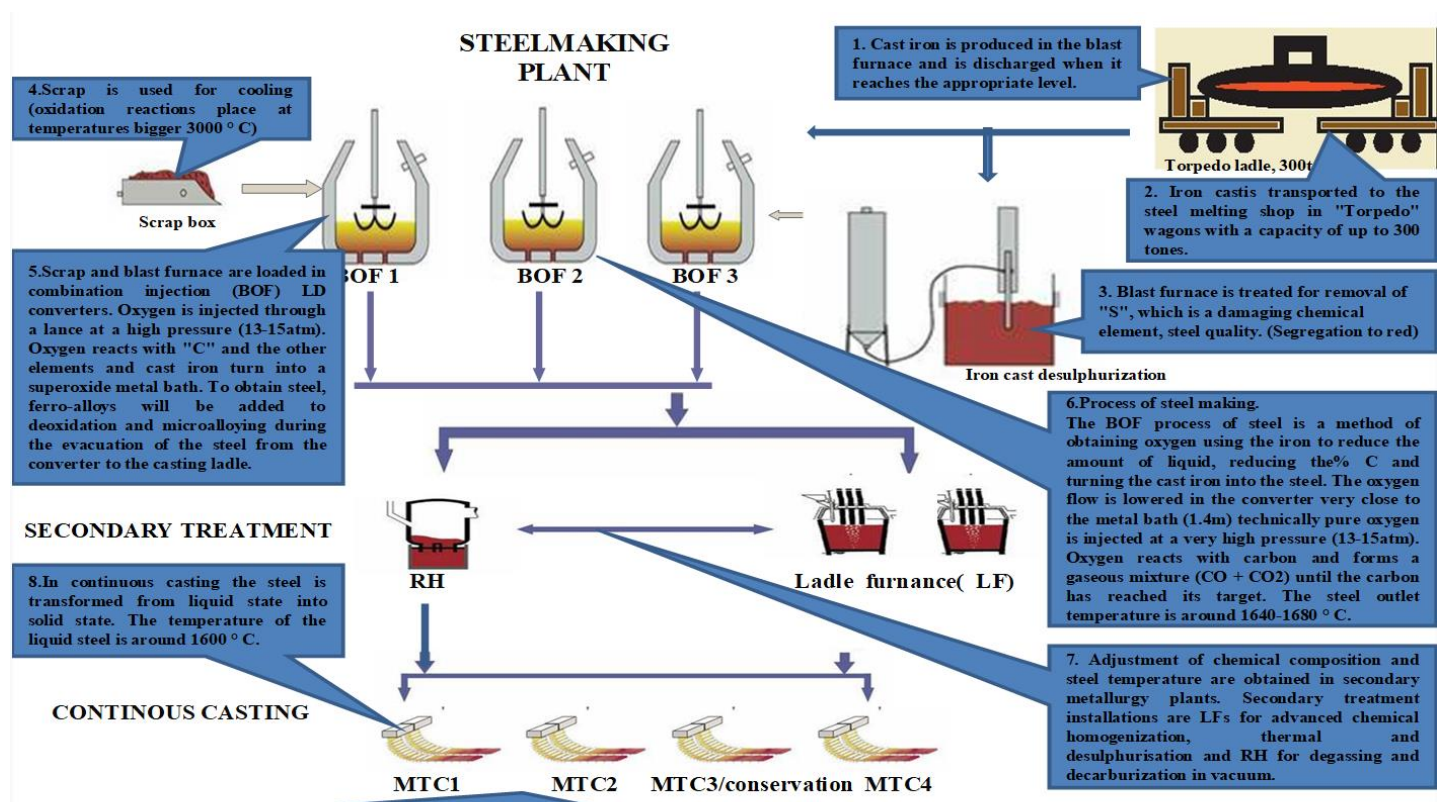

9. The crystallizer is the main component of the continuous casting machine. It has 4 double-walled electrolytic walls, cooled by water in which the steel flows and results in a long half-finished (slab). Continuous casting process of steel liquid steel can be poured on the bottom of the pot into an intermediate hopper, called mould. The temperature of the liquid in the dispenser is $25-35^{\circ} \mathrm{C}$ higher than the iiq ins temperature. Foliowing casting, a solid crist is obtained at the crystizaning are cuting with oxigaz after the length imposed by the mill. Before the stacking, the slabs are signaled marks for traceability.

Fig. 1. General presentation of the technological flows of making and casting steel $[1,4]$

\subsection{Physico-chemical processes in steelmaking and casting of X70}

In a LD converter with combined oxygen and argon blowing, Fig. 2, the basic reactions that take place are oxidation, and the movement of the metal bath is mainly generated by the energy transmitted by the oxygen jet hitting the metal bath and by the blowing energy, due to carbon monoxide (CO) formation and release [6].

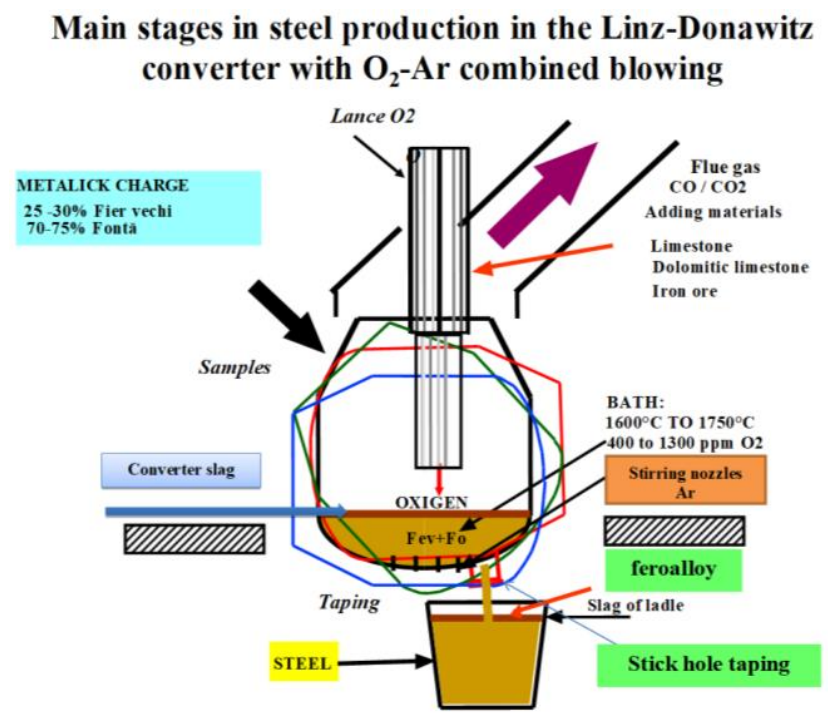

Fig. 2. Linz-Donawitz converter with combined blowing of the $\mathrm{O}_{2}-\mathrm{Ar}[1,8]$

In the initial phase of the process when the silica oxidation takes place, the formation of $\mathrm{CO}$ remains less intense. In the main decarburization phase, the formation of $\mathrm{CO}$ in the reaction areas of the oxygen jets and in the immediate vicinity is extremely pronounced. In the marginal areas of the converter, however, there are dead zones where variations of concentrations occur due to the differences in 


\section{THE ANNALS OF “DUNAREA DE JOS” UNIVERSITY OF GALATI \\ FASCICLE IX. METALLURGY AND MATERIALS SCIENCE \\ No. 1 - 2019, ISSN 2668-4748; e-ISSN 2668-4756 \\ Article DOI: https://doi.org/10.35219/mms.2019.1.09}

intensity of the oxidation reactions [7]. In the final phase of the decarburization, the combustion zones are less carbon-fuelled, due to an increased slag of iron and manganese.

In the bubbling process, the inert gas (nitrogen or argon) is injected into the batch through the bottom of the converter. The amount of gas varies depending on the phase of the elaboration process. During desilica and the main decarburization phase, the gas flow is sufficient to ensure the chemical composition and homogeneous temperature of the metal bath. In the final phase of decarburization and especially in advanced decarburization, the $\mathrm{CO}$ formation is too weak to generate the movement of the metal bath.

In this period the flow rate of the bubbling gas is increased to ensure the transport of carbon in the reaction areas of the oxygen jets and at the same time to prevent the slag from further oxidation of other elements. In the whole process, the reactions are close to equilibrium, balances that are reached in the postbubbling phase and the variation of the main elements concentration and of their oxides are shown in Fig. 3.

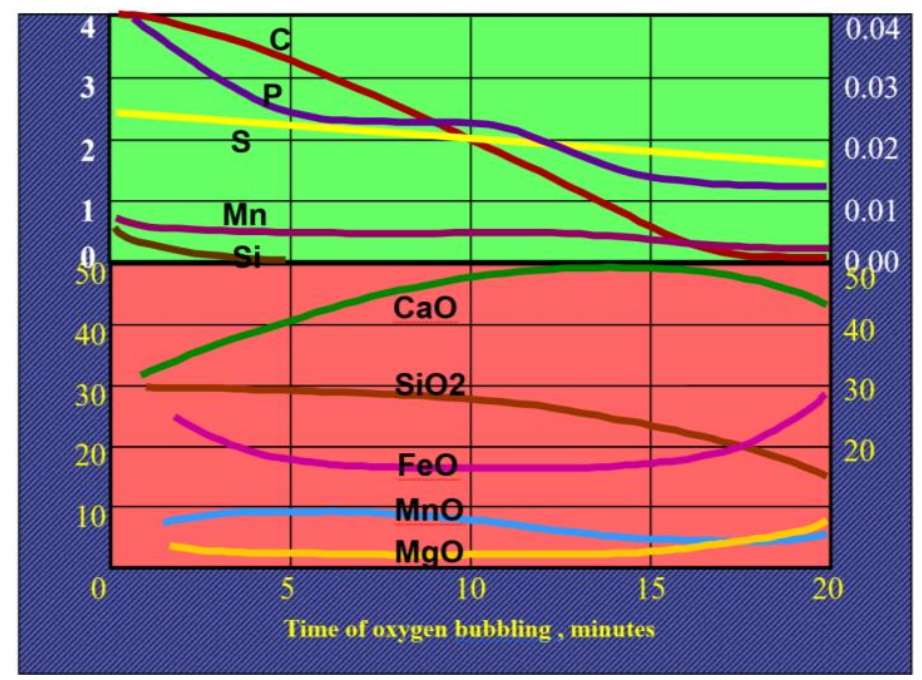

Fig. 3. Variation of different element and the resulting oxides concentration in the converter [4]

Continuous casting machine

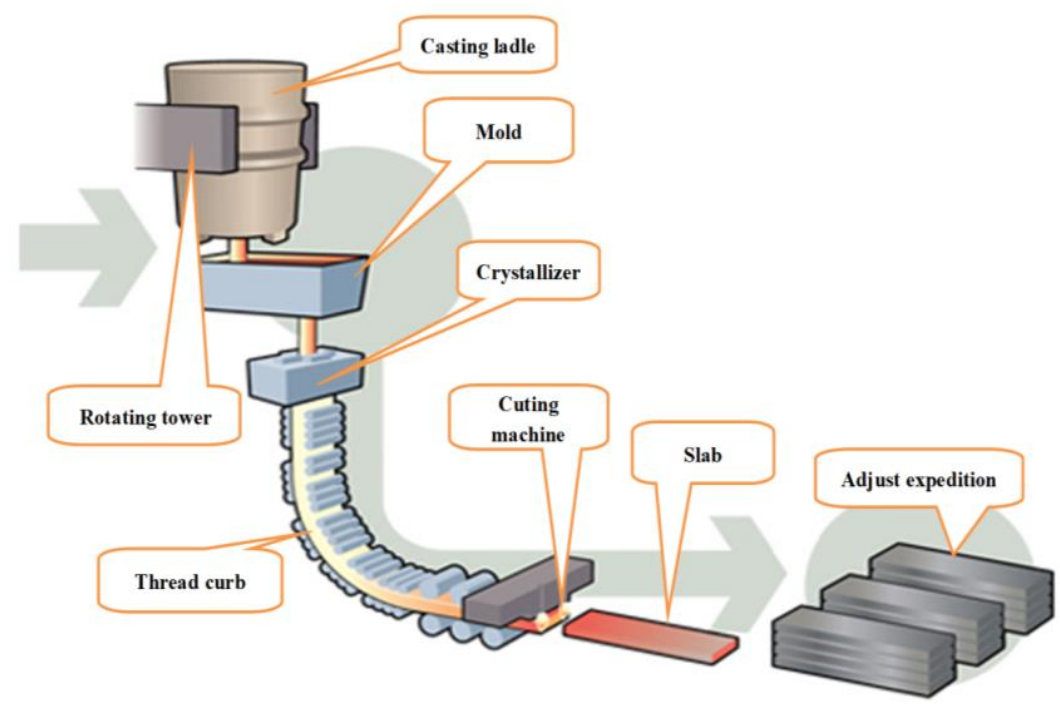

Fig. 4. Continuous casting machine, the main scheme [4, 5]

The bubbling process through the bottom of the converter helps the oxidation and slurry reactions of the formed oxides (oxides of silica, manganese, iron etc.) near the equilibrium state, during the main phase of the decarburization [8]. The equilibrium states between the chemical elements in the metal bath and 


\section{THE ANNALS OF “DUNAREA DE JOS” UNIVERSITY OF GALATI \\ FASCICLE IX. METALLURGY AND MATERIALS SCIENCE \\ No. 1 - 2019, ISSN 2668-4748; e-ISSN 2668-4756 \\ Article DOI: $\underline{\text { https://doi.org/10.35219/mms.2019.1.09 }}$}

the oxygen content are not perfectly achieved during oxygen bubbling. The lime dissolution is accelerated by injecting the inert gas into the metal bath. The addition of fluorine $\left(\mathrm{CaF}_{2}\right)$ for the fluidization of the slag is no longer necessary, which leads to increased durability of the refractory lining of the converter.

Examples of the defects types in slabs are presented in Table 7 and Fig. 7, 8 .

Table 6. Baumann analysis bulletin according to the Baumann-OLD1 Laboratory Analysis

\begin{tabular}{|c|c|c|c|c|c|c|}
\hline No. heat & No. slab & Quality & Sleb dimensions & Attack type & $\begin{array}{c}\text { Casting } \\
\text { machine }\end{array}$ & $\begin{array}{c}\text { Level of } \\
\text { segregation }\end{array}$ \\
\hline 911435 & 3 & $\mathrm{M} 21$ & $250 / 1900$ & $\begin{array}{c}\mathrm{CuCl}_{2}+ \\
\mathrm{NH}_{4} \mathrm{Cl}\end{array}$ & $1 / 1$ & Class 2 \\
\hline 911435 & 6 & $\mathrm{M} 21$ & $250 / 1900$ & $\begin{array}{c}\mathrm{CuCl}_{2}+ \\
\mathrm{NH} 4 \mathrm{Cl}\end{array}$ & $1 / 2$ & Class 1 \\
\hline
\end{tabular}

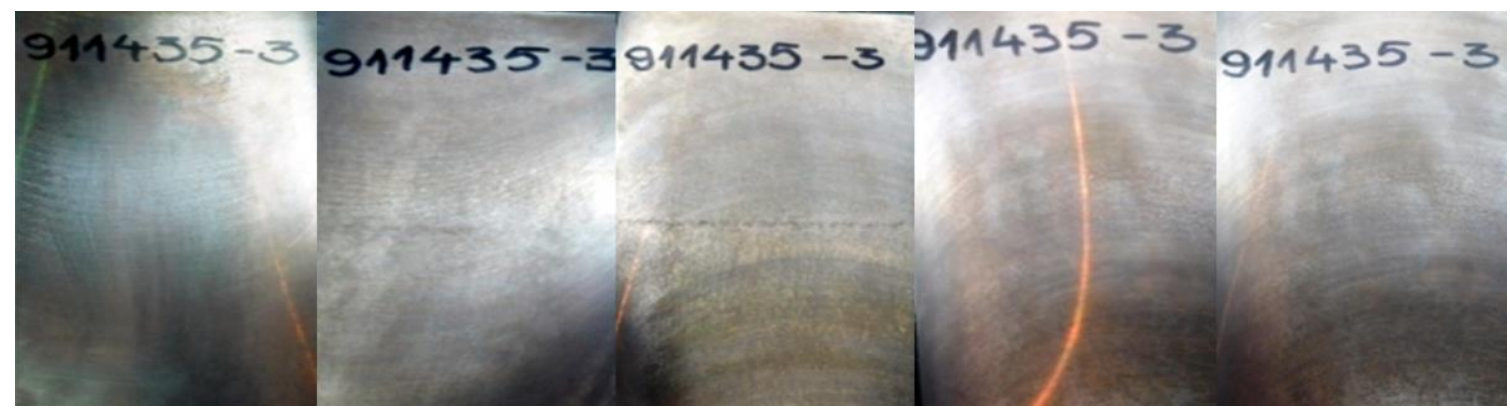

Fig. 5. Central segregation and defective core class 2, wire 1

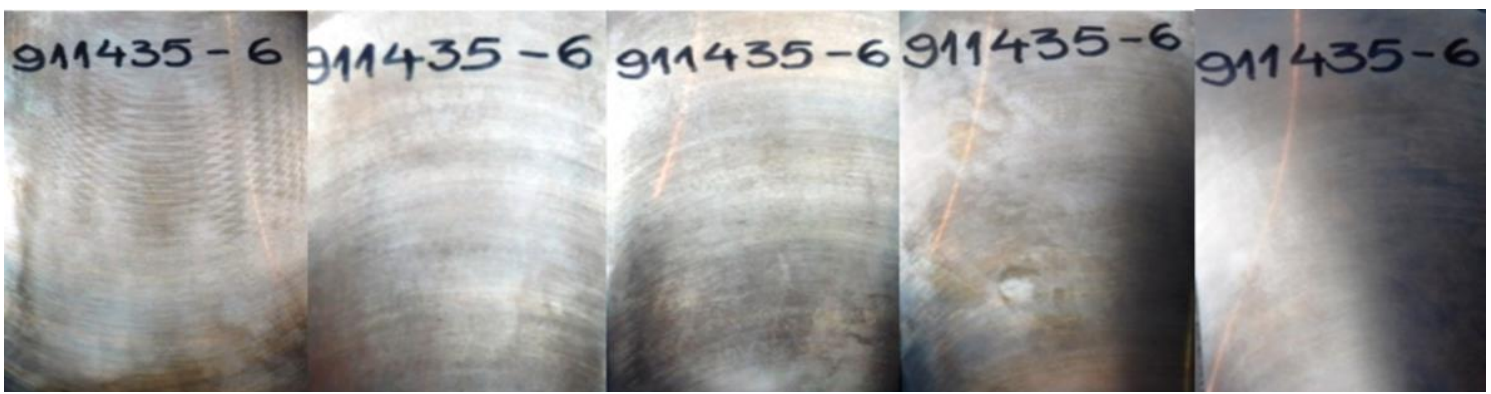

Fig. 6. Central segregation and defective core class 1, wire 2

Table 7. Faults in frames according to API-5L/95 [4, 5]

\begin{tabular}{|c|c|c|}
\hline Surface defects & Type & Causes \\
\hline \multirow{4}{*}{ Cracks } & longitudinal & longitudinal uneven cooling in the crystallizer \\
\cline { 2 - 3 } & transversal & $\begin{array}{c}\text { transversal adhesion of the steel to the walls of the } \\
\text { crystallizer }\end{array}$ \\
\cline { 2 - 3 } & lateral & lateral abrasions of the crystallizer walls \\
\cline { 2 - 3 } & marginal & marginal sealing improper at the beginning \\
\cline { 2 - 3 } & & temperature and high casting speed \\
\cline { 2 - 3 } $\begin{array}{c}\text { Microcavities and } \\
\text { non-metallic } \\
\text { inclusions }\end{array}$ & & defective alignment of the supporting rolls \\
\cline { 3 - 3 } & & low temperature of steel \\
\cline { 2 - 3 } & & oxidation of steel in crystallizer \\
\hline
\end{tabular}




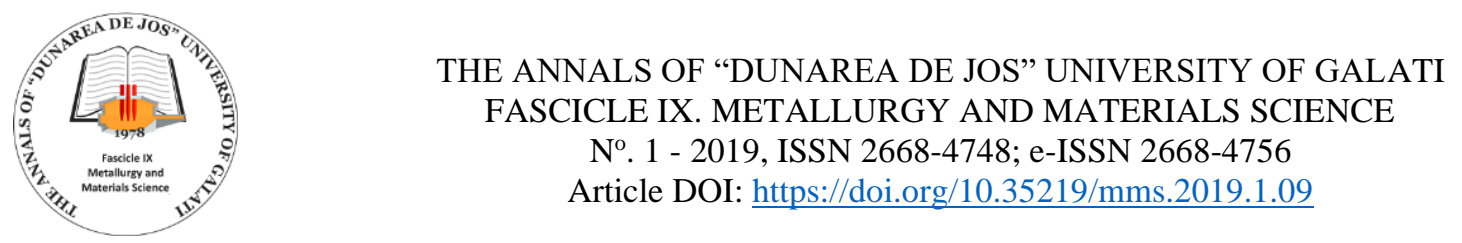

\begin{tabular}{|c|c|c|}
\hline & & inclusions of pouring powder \\
\hline & & impure steel with non-metallic inclusions \\
\hline & & driving crusts of solidified steel in crystallizer \\
\hline & & inadequate deoxidation of steel when making it \\
\hline \multicolumn{3}{|l|}{ Internal defects } \\
\hline \multicolumn{3}{|l|}{$\begin{array}{l}\text { Segregation at the } \\
\text { center and defective } \\
\text { cores }\end{array}$} \\
\hline \multirow{5}{*}{$\begin{array}{l}\text { Non-metallic } \\
\text { inclusions }\end{array}$} & \multicolumn{2}{|l|}{$\begin{array}{l}\text { inclusions of pouring } \\
\text { powder }\end{array}$} \\
\hline & local inclusions & excessive turbulent local of the steel in the crystallizer \\
\hline & slag inclusions & refractory exfoliated material \\
\hline & $\begin{array}{l}\text { inclusions in the form } \\
\text { of clouds }\end{array}$ & slag drive from distributor to crystallizer \\
\hline & $\begin{array}{l}\text { inclusions below the } \\
\text { surface }\end{array}$ & \\
\hline
\end{tabular}

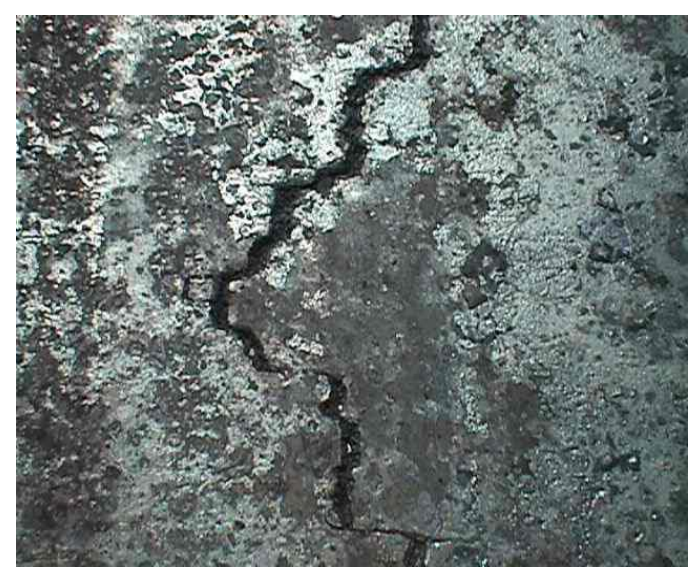

Fig. 7. Surface cracks

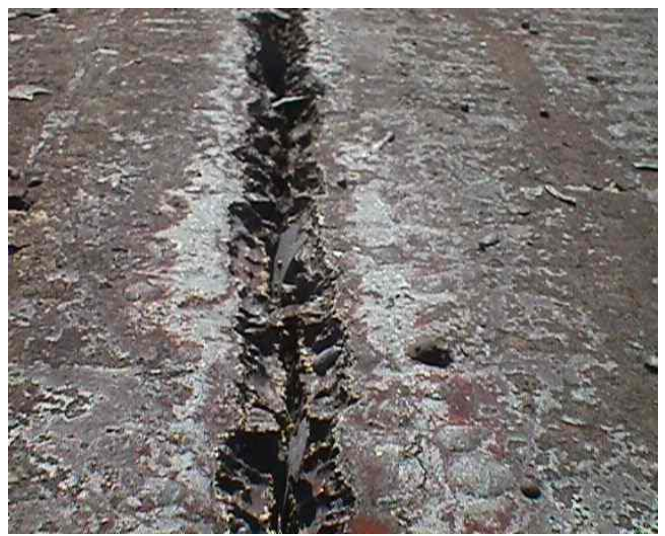

Fig. 8. Deep longitudinal cracks

Following some structural analysis presented in Fig. 9, it resulted that the microstructure noted with 1 shows that the analysed steel purity is very good, max. 1 in conformity with the existing standards. The steel is clean and globular inclusions rarely occur (sulphides modified as a result of their interaction with $\mathrm{Al}_{2} \mathrm{O}_{3}$ and $\mathrm{CaO}$ ). 


\section{THE ANNALS OF “DUNAREA DE JOS” UNIVERSITY OF GALATI \\ FASCICLE IX. METALLURGY AND MATERIALS SCIENCE \\ No. 1 - 2019, ISSN 2668-4748; e-ISSN 2668-4756 \\ Article DOI: https://doi.org/10.35219/mms.2019.1.09}

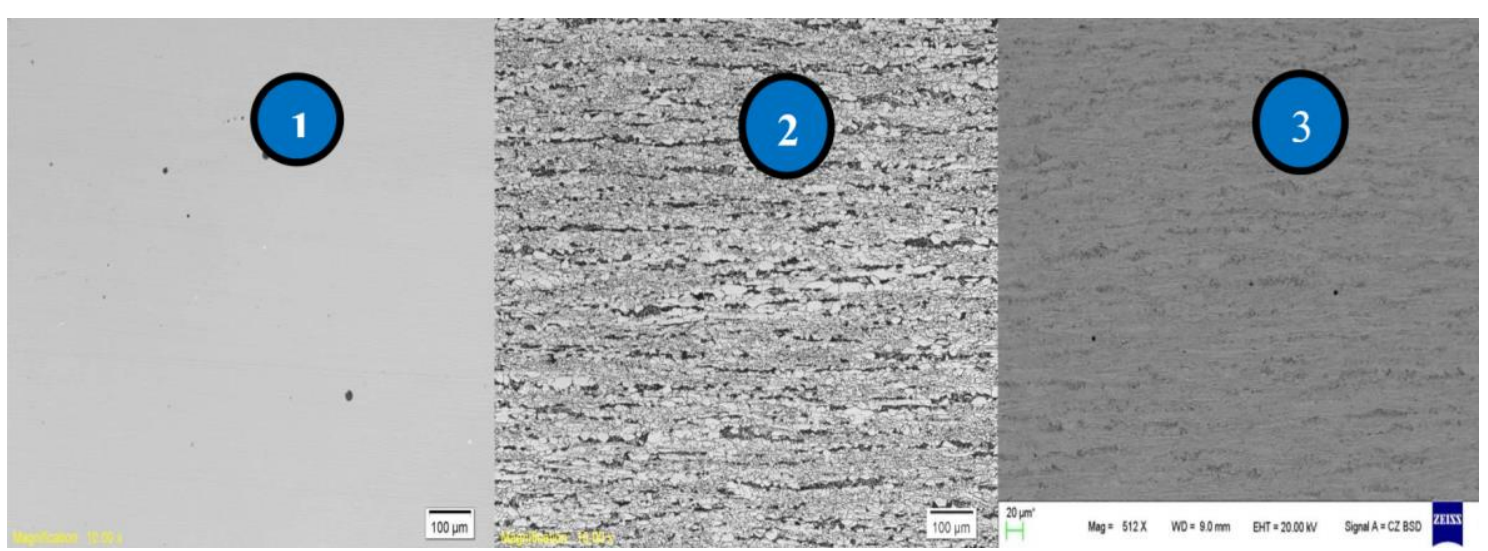

Fig. 9. SEM images of X70 steel samples (500x), according the, Central Laboratory analysis of Liberty Steel Group Galati

The microstructures noted with 2 and 3 are fine, with some granulation zones 8-9 and a ferrito-perlitic structure. These structures ensure good deformability [8].

\section{Conclusions}

For deoxidation and microalloying, iron alloys are used but they have strictly limited content of harmful elements (P, S). LF microalloying materials such as: $\mathrm{Mn}-99 \%$, Al-99\%, FeTi-70\%, FeV-80\%, FeNb-65\%, Ca-99\% or SiCa-60/30\% are introduced into the steel as tubular iron -alloys and not chunks.

In this way, the superior assimilation and homogeneous diffusion of the elements into the metal bath are achieved.

Secondary treatment of the X70 steel for chemical and thermal homogenization of the metal bath is achieved by advanced metal bath desulfurization using synthetic slag, lime and bauxite. Vacuum degassing with $\mathrm{RH}$ procedure is done to reduce hydrogen from $8-9 \mathrm{ppm}$ to less than $2 \mathrm{ppm}$. At the continuous casting of these steel types, the bubbling is not used because it is intended that the floating of inclusions be easier on the surface of the metal bath.

\section{References}

[1]. Toshihiko E. M. I., Steelmaking technology for the last 100 years: Toward highly efficient mass production systems for high quality steels, ISIJ International, vol. 55, no. 1, p. 36-66, 2015.

[2]. Siciliano F., Stalheim D. G., Gray M. J., Modern high strength steels for oil and gas transmission pipelines, Proceedings of the $7^{\text {th }}$ International Pipeline Conference, TMS, 2008.

[3]. Alexandru Rau, Iosif Tripsa, Steel metallurgy, Didactic and Pedagogical Publishing House Bucharest, 1973.

[4]. ***, Working procedures and instructions from OLD1-TC of Arcelor Mittal Galaţi, 2014.

[5]. Peng Fei, Yi Min, Cheng-jun Liu et al., Effect of continuous casting speed on mold surface flow and the related near-surface distribution of non-metallic inclusions, International 3. Journal of minerals metallurgy and materials, vol. 26, no. 2, p.186, 2019.

[6]. Tripşa I., Kraft N., Steelmaking in oxygen converters, Technical Publishing House, Bucharest, 1970.

[7]. Tripşa I., Pumnea C., Steel deoxidation, Technical Publishing House, Bucharest, 1981.

[8]. ***, Technological instructions specific to X60, X65, X70 steelmaking, ArcelorMittal Galati, OLD1, Steel Department, 2016. 